\title{
PPDM Kelompok UKM Rengginang di Desa Rasau Jaya 1
}

\author{
Linda Suwarni*1 $^{* 1}$ Eko Sarwono ${ }^{* 2}$, Edy Suryadi ${ }^{* 3}$, Selviana ${ }^{* 4}$ \\ 1,2,3,4* Program Studi Kesehatan Masyarakat, Universitas Muhammadiyah Pontianak \\ Jalan A. Yani No. 111 Pontianak \\ ${ }^{1}$ linda. suwarni@unmuhpnk.ac.id \\ eko.sarwonolunmuhpnk.ac.id \\ ${ }^{3}$ edy. suryadi@unmuhpnk. ac.id \\ ${ }^{4}$ selviana@unmuhpnk.ac.id
}

\begin{abstract}
Kelompok UKM Mekar Sari merupakan kelompok yang berada di Desa Rasau Jaya 1 yang melakukan usaha produksi rengginang. Permasahan yang dihadapi UKM tersebut adalah masih kemasan produk yang masih sederhana, dan proses produksi rengginang yang masih konvensional, terutama pada proses pengeringan. Hal ini akan menjadi permasalahan serius jika musim hujan tiba, produk yang dihasilkan terancam busuk sehingga menyebabkan kerugian yang besar. Selain itu, hygiene sanitasi anggota kelompok masih belum memenuhi syarat kesehatan. Target kegiatan ini adalah anggota kelompok memiliki kemampuan dan keterampilan dalam mengemas produk menjadi lebih menarik dan memenuhi syarat pemasaran, serta dapat menerapkan tenologi tepat guna berupa mesin pengering serba guna. Berdasarkan hal tersebut, maka perlu introduksi teknologi mesin pengering serba guna, dan pembelajaran dengan materi yang berkaitan dengan masalah yang dihadapi. Pembelajaran disampaikan dengan metode pendekatan sosialisasi, pelatihan, demonstrasi, dan pendampingan. Hasil kegiatan ini adalah pelaksanaan PPDM di kelompok UKM Mekar Sari (Rengginang) mendapat respon positif dari anggota kelompok. Hal ini terlihat dari antusiasme seluruh anggota kelompok mengikuti kegiatan dari awal sampai akhir, selanjutnya secara mandiri menerapkan introduksi IPTEKS yang diberikan dalam pengolahan dan pengemasan produk yang dihasilkan (Rengginang) dan tersedianya mesin pengering serbaguna serta meningkatkan pengetahuan dan keterampilan anggota kelompok dalam meneapkan hygiene sanitasi makana. Kemasan produk yang dihasilkan sudah menarik, tersedia PIRT, dan bahan yang digunakan.
\end{abstract}

Keywords - Rengginang, Mesin Pengering, Hygiene Sanitasi.

\section{Pendahuluan}

Desa Rasau Jaya Satu adalah salah satu desa yang ada di Kecamatan Rasau Jaya dengan luas 1.392,00 Ha, dengan jumlah penduduk 8.452 jiwa dan kepadatan 607,17 per km2. Mata pencaharian penduduk di desa ini sebagian besar sebagai petani $(66,77 \%)$, buruh $(16 \%)$, pedagang $(8,15 \%)$, dan Nelayan (4,62\%). Desa Rasau Jaya I memiliki 6 dusun (Suka Damai, Suka Bakti, Rejo Agung, Purwodadi, Kebun jeruk, dan Bina Karya), 14 RW, dan 65 RT. Desa ini merupakan kawasan transmigran di Kalimantan Barat yang menjadi pusat pertumbuhan dan Ibukota Kecamatan, yang menjadikan nilai strategis desa ini.

Kelompok UKM Mekar Sari adalah salah satu kelompok usaha kecil menengah yang ada di Desa Rasau Jaya 1 yang memproduksi Rengginang yang dikenal sebagai oleh-oleh khas dari Kecamatan Rasau Jaya. Berdasarkan hasil observasi dan wawancara yang telah dilakukan oleh tim menemukan kendala yang dihadapi antara lain kemasan produk yang masih sangat sederhana (belum mencantumkan merek dagang, PIRT, komposisi bahan yang terkandung, dan plastik kemasan yang kurang menarik). Selain itu, dalam proses pengeringan pembuatan produk Rengginang masih konvensional, hanya mengandalkan sinar matahari. Pada musim hujan, produk Rengginang terancam rusak, bahkan membusuk, sehingga menimbulkan kerugian yang besar bagi kelompok. Anggota kelompok belum sepenuhnya memahami tentang hygiene sanitasi pengolahan makanan. Hal ini karena keterbatasan pengetahuan dan teknologi yang dimiliki anggota kelompok.

Pemasaran berbagai produk lokal juga masih minim dan sangat terbatas. Hal ini mengakibatkan produksi yang ada tidak terpasarkan dengan optimal. Selain pemasaran yang menjadi masalah, kemasan produk industri rumah tangga (rengginang dan kerupuk) belum menarik dan variasi dari produk belum optimal, sehingga jika dilihat dari performance produk kurang menarik. Selain itu, berdasarkan informasi dan uji lab yang pernah dilakukan menunjukkan bahwa masih ada masyarakat yang menggunakan "pijar" (Boraks) pada produksi makanan rumah tangga, sehingga dapat berbahaya bagi kesehatan yang mengkonsumsi makanan yang mengandung Boraks (jangka panjang). Penyebabnya adalah masih minimnya pengetahuan masyarakat tentang bahaya penggunaan Boraks pada makanan, dan minimnya pengetahuan tentang inovasi penggunaan pengawet makanan yang boleh digunakan. 


\section{TARGET DAN LUARAN YANG DICAPAI}

Target luaran yang diharapkan dalam kegiatan PPDM ini adalah tersedianya teknologi mesin pengering serbaguna percontohan, kemasan produk rengginang yang menarik, meningkatkatnya pengetahuan dan keterampilan anggota kelompok tentang hygiene sanitasi makanan dan bahan pangan yang diperbolehkan. Selain itu juga, meningkatnya pemasaran produk khas yang dihasilkan dari kelompok UKM Mekar Sari.

\section{METODE PELAKSANAAN}

Adapun metode yang digunakan dalam melaksanakan pendampingan sekaligus pemberdayaan melalui melalui Program Pengembangan Desa Mitra (PPDM) Desa Rasau Jaya Satu sebagai sasaran kegiatan sebagai berikut:

1) Metode ceramah/diskusi : Metode ini dinilai lebih efektif memberikan pengetahuan dasar tentang hygiene sanitasi makanan, bahan tambahan pangan yang diperbolehkan, manajemen produksi, pengolahan dan pemasaran yang efektif dan efisien dengan didukung oleh modul-modul praktis.

2) Metode Demonstrasi : Bertujuan untuk mendemonstrasikan berbagai kegiatan yang akan dilakukan antara lain aplikasi packing produk variasi dan produk rengginang .

3) Metode Pendampingan : Metode ini dilaksanakan setelah dua metode di atas telah dilalui dan kelompok Mitra telah diyakini memahami materi-materi yang diberikan, selanjutnya dilakukan pemantapan dengan pendampingan berkelanjutan. Pendampingan diharapkan dapat memperbaiki sikap, perilaku, keterampilan dan kesadaran kelompok Mitra Kegiatan ini melibatkan sebanyak 4 orang mahasiswa dari Fakultas Ilmu Kesehatan, Ekonomi dan Bisnis, dan Teknik Mesin. Mahasiswa ini berperan sebagai pendamping tutor dalam introduksi IPTEKS yang akan ditransfer pada mitra selama kegiatan PPDM ini berlangsung. Selain itu, kegiatan ini juga menjadi bagian dari tugas akhir mahasiswa tersebut untuk mengukur keefektivitasan dan peningkatan yang terjadi selama kegiatan PPDM.

\section{HASIL DAN PEMBAHASAN}

Adapun hasil kegiatan program pengembangan desa mitra (PPDM) yang sudah terlaksana pada UKM Mekar Sari (Rengginang) adalah sebagai berikut:

\section{A. Sosialisasi PPDM dan Brainstorming}

Sosialisasi PPDM dimaksudkan agar mitra dapat mengerti dan mendukung serta bekerjasama dengan pelaksana kegiatan PPDM. Bila dukungan dan kerjasama dapat dilakukan dengan baik, keberhasilan tekhnologi introduksi dan penyebarluasannya (diseminasi) akan dapat dicapai dengan mudah. Kegiatan sosialisasi PPDM ini dilaksanakan bersamaan dengan pemetaan bersama mitra dan tokoh masyarakat serta brainstorming penyelesaian melalui teknologi yang akan diterapkan. Kegiatan sosialisasi IbM ini dipimpin oleh ketua tim yaitu Dr. Linda Suwarni, SKM, M. Kes.

Selain melakukan sosialisasi dengan mitra (UKM), sosialisasi dan audiensi ini juga dilakukan dengan BAPPEDA Kubu Raya, Pemerintahan Kecamatan Rasau Jaya, Pemerintahan Desa Rasau Jaya 1, dinas dan instansi terkait dalam perwujudan Desa Rasau Jaya sebagai Desa Sentra Agrobisnis dan Mandiri Berbasis Lokal, seperti dinas pertanian, dinas kesehatan, dinas perindustrian dan perdagangan, dinas sosial dan pemberdayaan masyarakat, dinas koperasi, usaha mikro, perdagangan dan perindustrian, dinas komunikasi dan informatika. Hasil kegiatan ini adalah pihak Bappeda Kabupaten Kubu Raya beserta jajarannya (dinas dan instansi terkait) siap mendukung dan bekerjasama dalam rangka mewujudkan Desa Rasau Jaya 1 sesuai dengan target dalam kegiatan PPDM ini.

Berdasarkan kegiatan sosialisasi dan brainstorming dengan para mitra PPDM, mitra mengungkapkan permasalahan produksi selama ini, mulai dari proses hingga pada pemasaran. UKM yang bergerak di bidang produksi rengginang mengungkapkan bahwa proses produksi selama ini yang bersifat manual membuat produksi menjadi terbatas, dan sangat tergantung pada cuaca. Jika cuaca tidak ada panas (turun hujan) maka produk ternacam busuk dan tidak dapat dijual. Selain itu, dalam proses packing produk juga masih sederhana dan belum ada merek dagang. Pemasaran selama ini bersifat pasif, yaitu hanya menunggu konsumen yang datang membeli.

\section{B. Promosi Hygiene Sanitasi Makanan pada pekerja di UKM Rengginang}

Promosi kesehatan sanitasi makanan dilakukan pada seluruh pekerja di UKM Rengginang, yaitu sejumlah 20 pekerja. Kegiatan ini dipimpin oleh seorang ahli Hygiene Sanitasi dan Kesehatan Lingkungan, yaitu Ibu Selviana, SKM, M.PH. Promosi kesehatan ini dilakukan dengan penyuluhan dan menggunakan media film dalam menyampaikan materi hygiene sanitasi makanan. Tujuan dilakukan kegiatan ini adalah untuk memberikan pengetahuan dan pemahaman kepada pekerja tentang kebersihan perorangan (personal hygiene), bahan tambahan makan yang diperbolehkan, hygiene sanitasi makanan, dan makanan yang memenuhi syarat kesehatan. Promosi kesehatan ini dibantu oleh 2 orang mahasiswa yang berasal Fakultas Ilmu Kesehatan Program Studi Kesehatan Masyarakat.

Sebelum dilakukan kegiatan promosi kesehatan tentang hygiene sanitasi makanan, dilakukan pre test untuk mengukur pengetahuan, sikap, dan praktek hygiene sanitasi makanan para pekerja. Pemberian promosi kesehatan tentang hygiene sanitasi dilakukan dengan metode interaktif dan tanya jawab. Peserta kegiatan ini juga diputarkan film tentang pentingnya hygiene sanitasi dan dampaknya jika tidak dilakukan bagi 
kesehatan. Peserta sangat antusia terhadap materi yang disampaikan dan film yang diputarkan. Hal ini terbukti dengan banyaknya peserta yang bertanya lebih lanjut dan mengutarakan pertanyaan-pertanyaan seputar materi yang disampaikan. Setelah 1 minggu dilakukan promosi kesehatan maka dilakukan post test kepada peserta untuk mengetahui efektivitas promosi kesehatan yang sudah dilakukan terhadap pengetahuan, sikap dan praktek tentang hygiene sanitasi.
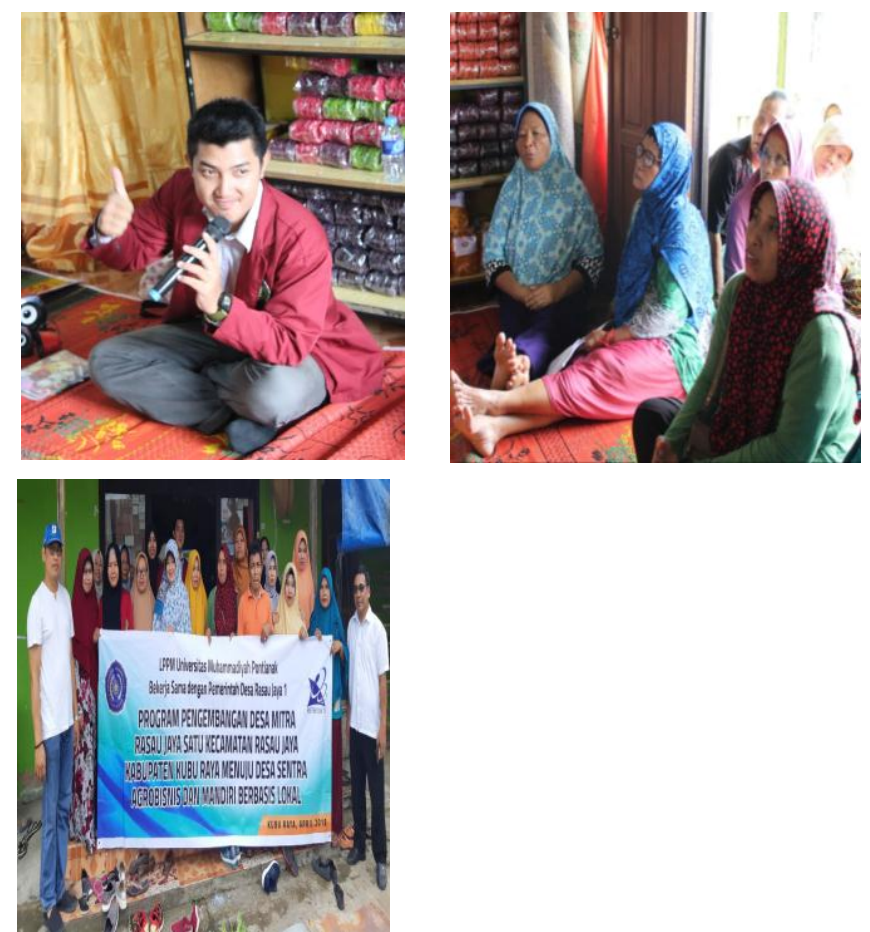

Gambar 1. Promosi Hygiene Sanitasi Makanan pada pekerja di UKM Rengginang

\section{Pemeriksaan Kesehatan pada pekerja di Mitra PPDM (UKM Mekar Sari)}

Pada kegiatan ini dilaksanakan pemeriksaan Asam Urat, Kolesterol, dan Gula Darah sebagai deteksi awal pemeriksanaan penyakit tidak menular (PTM). Pemeriksanaan ini dilakukan di rumah ketua UKK Mekar Sari yaitu Ibu Lina Kunayah sebanyak 20 orang pekerja melakukan pemeriksaan. Sebanyak 12 petani terdeteksi mengalami kolesterol tinggi, 15 asam urat serta 10 orang gula darahnya melebihi ambang batas.

Setelah itu dilakukan promosi kesehatan mengenai Pencegahan PTM (Penyakit Tidak Menular). Materi ini disampaikan oleh Bapak Abdul Haris Djauhari, M.Kes dari Dinas Provinsi Kalimantan Barat. Dengan demikian diharapkan para petani dapat mewaspadai dan mencegah PTM sejak awal.

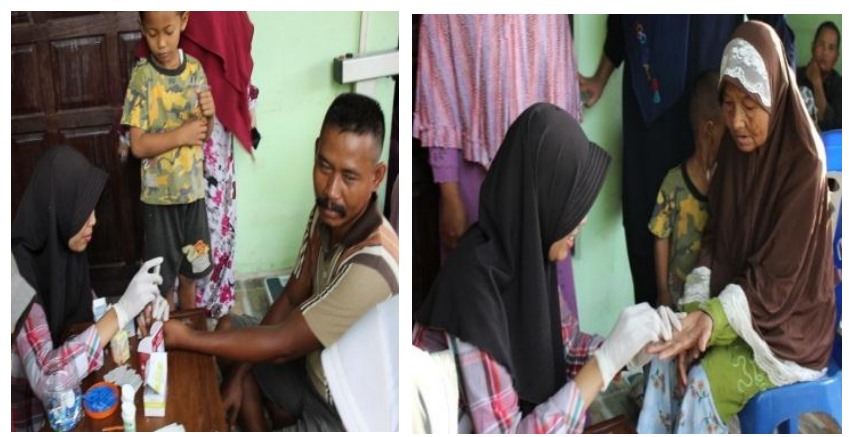

Gambar 2. Pemeriksaan Kadar Gula Darah, Kolesterol, dan Asam Urat (PTM) pada pekerja UKM Mekar Sari

\section{Pelatihan Kewirausahaan dan Packing Produk pada kelompok UKM Mekar Sari (Rengginang)}

Pelatihan kewirausahaan praktek packing produk ini dipimpin oleh seorang tenaga ahli ekonomi dari Inkubator Bisnis Indonesia yaitu Bapak Sukardi, SE. Pelatihan kewirausahaan ini dimaksudkan untuk memberikan pengetahuan pada kelompok mitra tentang dunia wirausaha, pada kegiatan ini disampaikan tentang jiwa wirausaha, modal, pengemasan produk, pemasaran dan perizinan.

Mitra diajarkan pembuatan merk, pemilihan kemasan, dan mengemas produk sehingga menarik. Mitra ditunjukkan contoh plastik kemasan yang menarik, kemudian diberikan contoh stiker merk yang sudah ada nama merk, komposisi, dan slogan produk. Metode demonstrasi digunakan dalam pelatihan packing produk. Peserta sangat antusias mengikuti kegiatan ini. Kemasan yang semula hanya menggunakan plastik es, dirubah menggunakan plastik kemasan dan merk dengan warna dan gambar yang menarik. Untuk selanjutnya mitra akan didampingi dalam pembuatan PIRT di Dinas Kesehatan Kabupaten Kubu Raya. Harapannya setelah produk dikemas dengan menarik dan memiliki PIRT diharapkan pemasaran produk ini dapat lebih luas dan produksi produk ini dapat berkelanjutan (tidak hanya pada musim tertentu saja).

Kelompok mitra antusias dalam mengikuti kegiatan ini. Mereka banyak mengajukan pertanyaan seputar wirausaha dan packing produk kepada pemateri. Dengan metode ceramah dan tanya jawab serta demonstrasi diharapkan mitra dapat lebih memahami materi yang disampaikan. Hasil kegiatan ini adalah kelompok mitra dapat mengetahui solusi atas permasalahan selama ini. Setelah kegiatan ini dilakanakan dilanjutkan dengan pelatihan pengemasan produk. Selain itu, penyelenggaraan kegiatan PPDM ini juga melibatkan sebanyak 2 orang mahasiswa dari Fakultas Ekonomi sebagai tenaga pendamping tekhnis selama pelatihan. Pelatihan dilaksanakan selama satu hari dengan metode ceramah dan diskusi serta tanya jawab. 

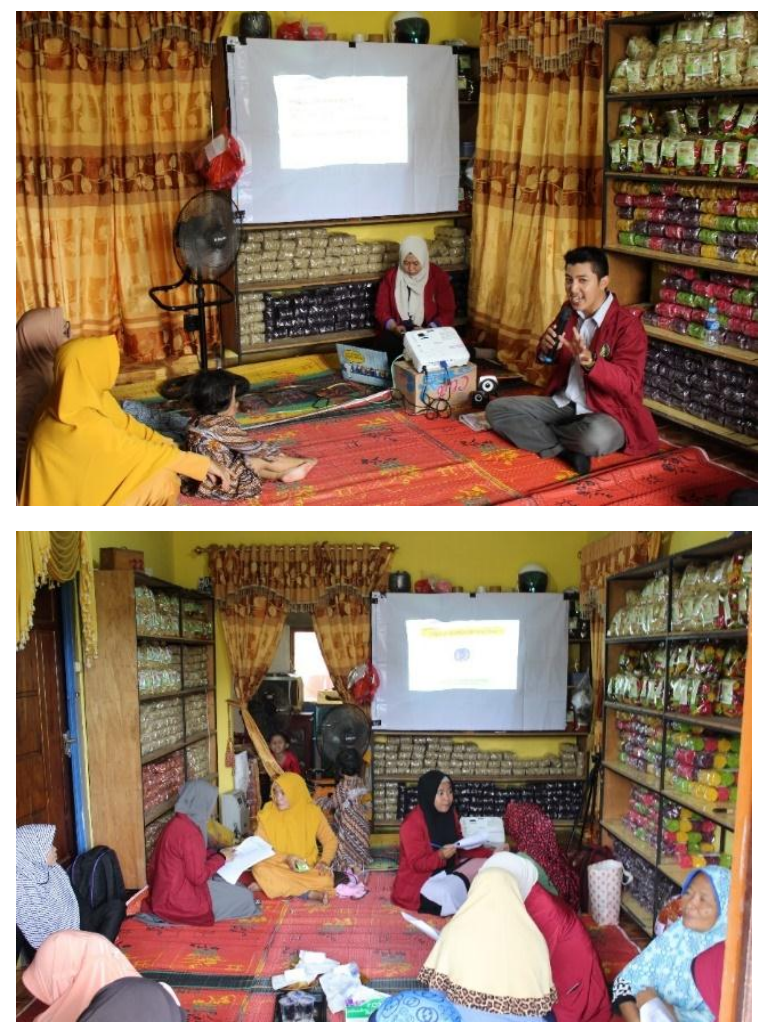

Gambar 3. Pelatihan Kewirausahaan dan Packing Produk pada kelompok UKM Mekar Sari (Rengginang)

\section{E. Introduksi teknologi mesin pengering percontohan}

Introduksi teknologi mesin pengering percontohan merupakan salah satu solusi dalam menghadapi kendala pengeringan pada kelompok UKM Mekar Sari yang selama ini hanya mengandalkan sinar matahari dalam proses pengeringan produk.

Mesin pengeringan percontohan ini didesain oleh tim PPDM UM Pontianak, yaitu Bapak Eko Sarwono, ST, MT. Diharapkan melalui mesin pengering ini, produksi rengginang pada kelompok UKM Mekar Sari tidak terkendala pada saat musim hujan tiba.
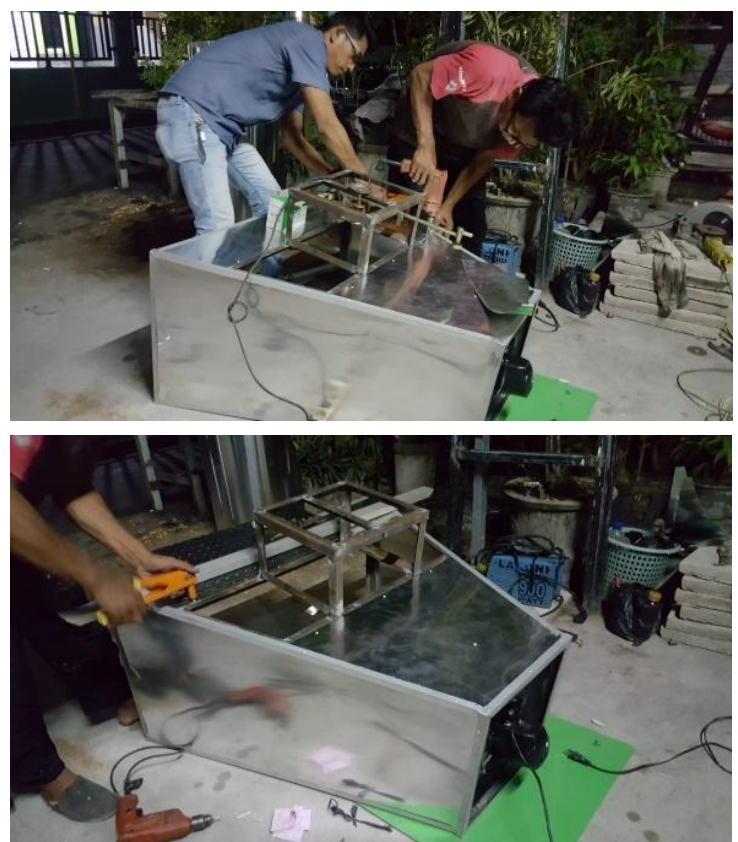

Gambar 5. Proses pembuatan mesin pengering percontohan bagi UKM Mekar Sari

\section{KESIMPULAN}

- Tahapan pelaksanaan kegiatan PPDM di Kelompok UKM Mekar Sari (Rengginang) di Desa Rasau Jaya 1 Kecamatan Rasau Jaya Kabupaten Kubu Raya terdiri atas kegiatan sosialisasi dan brainstorming, promosi hygiene sanitasi makanan, pelatihan kewirausahaan dan packing produk serta intoduksi mesin pengering percontohan. Kegiatan pendampingan telah dilakukan sesuai dengan rencana yang terjadwal.

- Pelaksanaan PPDM pada kelompok UKM Mekar Sari (Rengginang) di Desa Rasau Jaya 1 Kecamatan Rasau Jaya Kabupaten Kubu Raya mendapatkan repson yang positif dari anggota kelompok UKM Mekar Sari. Hal ini dapat dilihat dari antusiasme anggota UKM yang mengikuti rangkaian kegiatan PPDM dari awal sampai akhir pada tahun pertama, selanjutnya secara mandiri menerapkan IPTEKS yang diberikan.

\section{UCAPAN TERIMAKASIH}

Direktorat Riset dan Pengabdian Kepada Masyarakat. Kementerian Riset, Teknologi, dan Pendidikan Tinggi yang telah mendanai kegiatan ini. 
Jurnal Pengabdian Masyarakat J-DINAMIKA, Vol. 3, No. 2, Desember 2018,

P-ISSN: 2503-1031, E-ISSN: 2503-1112

\section{DAFTAR PUSTAKA}

[1] Diana Herawati, 2011. Pedoman Pendaftaran Rumah Pengemasan. Direktorat Jenderal Pengolahan dan Pemasaran Hasil Pertanian. Bogor.

[2] Harimurti Subanar. (1998). Manajemen Usaha Kecil. Yogyakarta : BPFE UGM

[3] Pemerintahan Kecamatan Rasau Jaya. (2015). Profil Kecamatan Rasau Jaya Kabupaten Kubu Raya.

[4] Rahardja, Pratama dan Manurung, Mandala. Teori ekonomi Mikro Suatu Pengantar Edisi Revisi (Jakarta: Lembaga Penerbit Fakutlas Ekonomi UU, 2002)

[5] Tjiptono, F. 1999. Strategi Pemasaran. Yogyakarta: Andi Offset 